\title{
The Effect of Soil PH, High-Calcium Compost and Cadmium on Some of Growth Characters in Corn (Zea maysl.)
}

\author{
Rabah S. Shareef ${ }^{1^{*}}$, Awang Soh Mamat ${ }^{2}$, Mustafa R. Al-Shaheen ${ }^{3}$ \\ ${ }^{1}$ College of Applied sciences, University of Anbar, Iraq. \\ ${ }^{2}$ School of Bioprocess Engineering, University Malaysia Perlis, Perlis, Malaysia. \\ ${ }^{3}$ College of Agriculture, University of Anbar, Iraq.
}

*Corresponding Author: Rabah S. Shareef, College of Education-Al-Qiam, University of Anbar, Iraq

\begin{abstract}
A pot experiment was carried out in the plastic greenhouse at the Institute of Sustainable Agrotechnology (INSAT), University Malaysia Perlis in Sungai Chuchuh, Perlis, Malaysia. During season of the cultivation of 2014 investigate the impact of soil pH, types of compost and cadmium (Cd) on Plant height, Leaf area and Leaf area index of corn plant (Zea mays L.). Fifty were arranged in factorial experiments according to the Complete Randomized Design (CRD), with three replicates. Five levels of soil pH were, pH4, pH5.2 (i.e., the original value), pH6, pH7 and pH8, two types of compost, market compost (MC) and product compost $(P C)$ and five levels of $C d ; C d 1, C d 2, C d 3, C d 4$ and $C d 0$ where the amounts $(2,4,6,8$ mg. $\mathrm{kg}-1$ soil and control treatment without add $\mathrm{Cd}$ ) are applied as CdCl2. Thus, the total numbers of pots were 150 pots. The results showed the soil pH 6 led to significant effect in increase the Plant height, Leaf area and Leaf area index. While adding the compost (PC) to increase the Plant height, Leaf area and Leaf area index as well as, increase concentration of Cd led to significant decreasing in Plant height, Leaf area and Leaf area index.
\end{abstract}

Keywords: pH of Soil, Compost, Calcium, Cadmium, Corn, Perlis.

\section{INTRODUCTION}

Soil $\mathrm{pH}$ is one of the important factors affecting soil fertility and plant nutrition because of it's the large contribution in the soil's ability to process the correct ratio of nutrients needed by the developing plant. Soil $\mathrm{pH}$ is also one of the important indicators to the need of soil of the nutrients during fertilization process to reclaim and improve soil fertility to meet the plant nutrients needs. Soil $\mathrm{pH}$ can impact the growth of a plant based on its influence on the availability of essential plant nutrients (Tran and Popova, 2013).

Acidity per se is not harmful to plants except in extreme cases (Shrivastava and Kumar, 2015). The problems of plant growth on acid soils are mainly due to the large amounts of $\mathrm{Al}, \mathrm{Fe}$ and $\mathrm{Mn}$ (Giller, 2001). Soil acidity is a major growth-limiting factor for some plant species in many parts of the world especially in tropical and subtropical countries. De Jong (2007) concluded that low soil pH is the number one growth-limiting factor with the most fertility problems in the tropics. Maize yields are significantly affected by acidity in the tropics (Kimatu, 2015). The primary effect of high $\mathrm{pH}$ for soil is inhibition of root growth, resulting in shoot growth reductions (Musharo, 2005). The low pH of soils are not suitable for the cultivation of maize where that the growth in the degree of soil pH 5 is bad because of the toxic materials. These materials (aluminum and iron) lead to disorder in the process of nutrition and its exchange, where it contributes to the decrease of the yield, but develops well when the soil pH is neutral (Fernánde and Hoeft, 2009).

Compost application to soils has contributed to increased plant height and leaf area index of corn significantly $(\mathrm{p}<0.001)$ as compared to the controlled (soil-only) treatment (Desalegnet al., 2014). The corn plant height develops increasingly in the time of planting in the soil with different rates of compost application (John et al., 2013). Cations that are essential for plant growth are $\mathrm{K}, \mathrm{Mg}, \mathrm{Ca}, \mathrm{Mn}$ and $\mathrm{Fe}$ (Bolan et al., 2003). Ozgenet al. (2011) noted the important roles of calcium on plant growth and development including cell division and cell elongation is well documented. Among the different levels of $\mathrm{Ca}, 6 \%$ level of $\mathrm{Ca}$ showed significant increase in plant height and number of plant branches 
(Ilyaset al., 2014). Madaniet al.(2013) showed that the increasing of calcium concentration in nutrition solution enhanced stem length and diameter of papaya seedlings.

Among Cd sensitive plants, corn has a high tolerance to $\mathrm{Cd}$ (sorghum $<$ cucumber $<$ wheat $<$ corn), with an effective concentration value (EC50) in Cd-amended soils ranging between 208 and 265 mg.kg- (An, 2004). Plant exposure to $\mathrm{Cd}$ caused main damage at cellular and physiological level (Benavides et al., 2005). Soil contamination with heavy metals is important problem that hampers plant growth. Wheat and corn are the main crops cultivated in the world and served as staple food in different parts of the world. Shoot and root growth of wheat was inhibited by the addition of $\mathrm{Cd}$ in nutrient media (Amani, 2008). Biomass reduction was observed in corn plant as its exposure to Cd. $\mathrm{Cd}$ affect photochemical efficiency, induced oxidative stress and membrane damage (Ekmekci et al., 2008). Growth characters such as root length and shoot height were decreased with increasing Cd soil addition (Auda et al., 2011).

Soil $\mathrm{pH}$ is considered a primary factor controlling the availability of $\mathrm{Cd}$ in soils, because the increase of soil $\mathrm{pH}$ favors the adsorption of $\mathrm{Cd}$ to metal binding sites and decreases the partition of $\mathrm{Cd}$ to soil solution (Kukieret al., 2004; Li et al., 2011). Kirkham (2006) confirms that the pH of the soil is usually the most important factor that controls the uptake, with low $\mathrm{pH}$ favoring $\mathrm{Cd}$ accumulation. Cadmium concentration in crops is influenced by a wide range of factors including crop genetics and soil characteristics such as texture, $\mathrm{pH}$, crop management practices and soil $\mathrm{Cd}$ concentration (Cynthiaet al., 2010).

Corn (or maize) is one of the oldest human-domesticated plants. Known as the third largest planted crop in the world after wheat and rice. It is mostly used as a primary feed crop - for instance it accounts for $95 \%$ of the total feed grain production and its use in the United States. Corn is also important as a food crop in many parts of the world, and in food processing for making starch, sweeteners, oil and beverage. Besides food and feed, nowadays corn has been playing an important role in industrial ethanol production (Shi, 2014 ; Qiu, et al., 2010).

\section{Materials ANd Methods}

\subsection{Experimental Design and Treatments}

Agricultural experiment was performed inside the plastic greenhouse and arranged by factorial experiments according to the Completely Randomized Design (CRD), with three replicates. This experiment is consisted of two types of compost (PC and MC),five levels of $\mathrm{pH}$ value in the soil (4, 5.2, 6, 7 and 8) and five levels of cadmium; $\mathrm{Cd} 1, \mathrm{Cd} 2, \mathrm{Cd} \mathrm{3,} \mathrm{Cd} 4$ and $\mathrm{Cd} 0$ where the amounts it were $(2,4,6,8 \mathrm{mg}$. $\mathrm{kg}-1$ soil and control treatment without add cadmium) are applied as $\mathrm{CdCl} 2$. The five of corn plants were planted for each treatment in plastic pots $(20 \mathrm{~cm} \times 20 \mathrm{~cm} \times 20 \mathrm{~cm})$. Where were packed with sandy loam soil, and it were irrigated daily by a drip irrigation system.

\subsection{Management of the Experiment}

The soil preparation was conducted before eight weeks of cultivation. Soil $\mathrm{pH}$ was adjusted to 4.0, 5.2 (i.e., the original value), 6.0, 7.0, and 8.0 by adding a $2 \mathrm{ml}$ solution of $0.15 \mathrm{M} \mathrm{HCl}$, distilled $\mathrm{H} 2 \mathrm{O}$ and $0.06 \mathrm{M}, 0.15 \mathrm{M}$, and $0.6 \mathrm{M} \mathrm{NaOH}$, respectively to $20 \mathrm{~g}$ of soil aerobically dried (WeymanKaczmarkowa and Pędziwilk, 2000). A complete amount of $10 \mathrm{~kg}$ soil was used for each treatment. Then, 200 g. Kg-1 soil was added from two types of compost - Product Compost (PC) table (1), which was produced in the second experiment of our study and Market Compost (MC) that was bought from local markets. These two types of compost were been mixed thoroughly with soil until full homogeneous and then put in the pots $(20 \mathrm{~cm} \times 20 \mathrm{~cm} \times 20 \mathrm{~cm})$ and incubated it in the laboratory at $25^{\circ} \mathrm{C}$ for eight weeks beginning with 20th January 2015.During incubation, the pots were irrigated with water and after six weeks of incubating of the soil all the amount of $\mathrm{Cd}$ were added to the soil for guaranteed of uniform distribution of Cd. A fertilizer rate of $60 \mathrm{~N} \mathrm{~kg}$.ha-1, $60 \mathrm{P} \mathrm{kg.ha-1}$ and $40 \mathrm{~K}$ kg.ha-1 for the maize was followed recommendation by (MARDI). The fertilizers used were urea $(46 \% \mathrm{~N}), \mathrm{CIRP}(30 \% \mathrm{P} 2 \mathrm{O} 5)$ and MOP $(60 \% \mathrm{~K} 2 \mathrm{O})$. Each seedling was transferred from transplant tray to each pot, which contained $10 \mathrm{~kg}$ of soil. The plants irrigation was an average of five minutes per day, using drip irrigation system. Also the agronomic practices like weeding were performed as and when necessary. These plants were allowed to grow till they hit the maturity level. All the plants were planted on 13th March 2015 and were harvested after 110 days. 
The Effect of Soil Ph, High-Calcium Compost and Cadmium on Some of Growth Characters in Corn (Zea Maysl.)

Table1. Product compost (PC) specifications and ratios of some important nutrients

\begin{tabular}{|c|c|c|c|c|c|c|c|c|c|c|}
\hline $\mathbf{p H}$ & $\begin{array}{c}\mathbf{C E C} \\
\mathrm{Coml.} \mathrm{Kg}^{-}\end{array}$ & $\begin{array}{c}\mathbf{O M} \\
\% \mathrm{dm}\end{array}$ & $\begin{array}{c}\mathbf{A s h} \\
(\%)\end{array}$ & $\begin{array}{c}\mathbf{C} \\
(\%)\end{array}$ & $\begin{array}{c}\mathbf{N} \\
(\%)\end{array}$ & $\begin{array}{c}\mathbf{C a} \\
(\%)\end{array}$ & $\begin{array}{c}\mathbf{M g} \\
(\%)\end{array}$ & $\mathbf{K}(\%)$ & $\begin{array}{c}\mathbf{P} \\
(\%)\end{array}$ & $\mathbf{C} / \mathbf{N}$ \\
\hline 8.03 & 29.91 & 38.7 & 22.168 & 43.24 & 1.64 & 4.29 & 0.60 & 1.02 & 1.26 & 26.37 \\
\hline
\end{tabular}

\subsection{Statistical Analysis}

Data were subjected to statistical analysis using the statistical software GenStat (Payne et al., 2012). ANOVA was used to analyze the experimental results of dependent variables (treatments). The least significant difference (LSD) was calculated at $\mathrm{P} \leq 0.05$.

\subsection{Plant Parameters of Study}

Plant height was measured from the soil surface until the flag leaf on average for five plants using ruler. After plants had been harvested, leaves were cut from the stem behind the collar of each plant. With the use of the LI-3100 leaf area meter the leaf area of all the photosynthetic active leaves was determined. Leaf area was measured in square centimeter $(\mathrm{cm} 2)$ (Wessels, 2014).Leaf area index (LAI) was calculated as the ratio of leaf to ground area by using the following formula given by (Watson, 1952).

LAI = Leaf area /Ground area

\section{RESULTS AND DISCUSSION}

\subsection{Plant Height (cm)}

Figure 3.1 indicated a big difference between the soil's $\mathrm{pH}$ levels in the plant height, where a $\mathrm{pH} 6$ is superior over the other levels, resulting in the highest rate that reached $171.97 \mathrm{~cm}$, whereas a $\mathrm{pH} 8$ resulted in the lowest rate that reached $158.32 \mathrm{~cm}$. This decrease might be caused by the nutrients not being absorbed by the plant at $\mathrm{pH} 8$, where it reached the highest level of soil $\mathrm{pH}$, and after soil incubation, it reached a $\mathrm{pH}=9.80$. This result agrees with Unagwu et al. (2013).

Figure 3.2 indicated a big difference in the plant height between two types of composts being used, where PC is remarkably superior over MC, resulting in the highest plant height that reached 174.32 $\mathrm{cm}$, while MC gave the least rate that reached $158.45 \mathrm{~cm}$. This increase in plant height is most likely caused by the availability of the nutrients necessary for plant growth in the PC compost more than MC compost, especially $\mathrm{N}$, which is the most important element in plant growth, and $\mathrm{Ca}$, which enhances plants' cells division (Kader and Linolberg, 2010; Ilyas et al., 2014). This result agrees with Makinde, (2007) nadLaekemariam and Gidago, (2012).

In the levels of $\mathrm{Cd}$, it might be remarkably superior to $\mathrm{Cd} 0$ in providing the highest level of plant height that reached $187.52 \mathrm{~cm}$, which is remarkably superior to the rest of Cd levels in terms of the rate of decrease of plant height with increasing Cd concentration in the soil, until it reaches $141.69 \mathrm{~cm}$ at $\mathrm{Cd} 4$. This decrease was most likely due to the effect of the high concentration of $\mathrm{Cd}$, as shown in Figure 3.3, which lead to the nutrients' absorption weakness that enhance plant growth (Prasad et al., 2001).

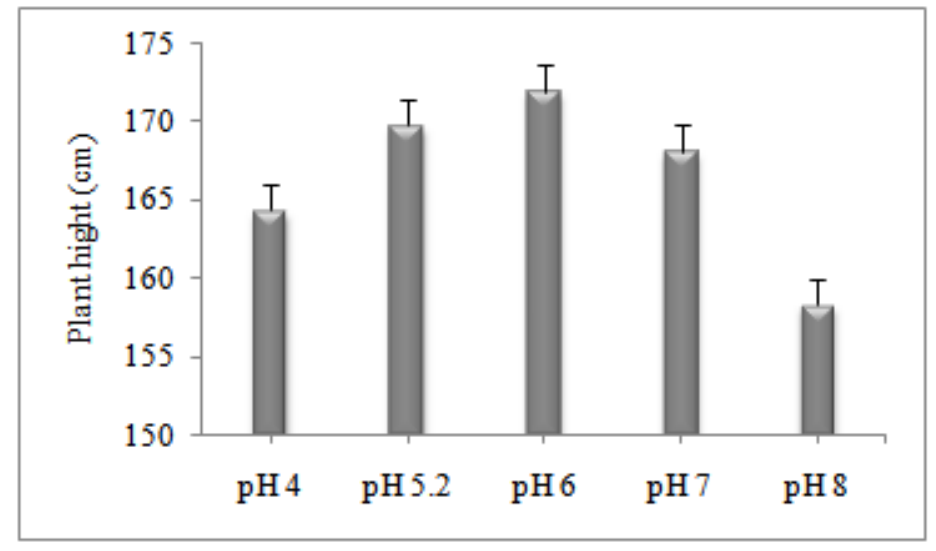

Figure3.1. Effect of soil $p H$ levels on plant height $(\mathrm{cm})$ 


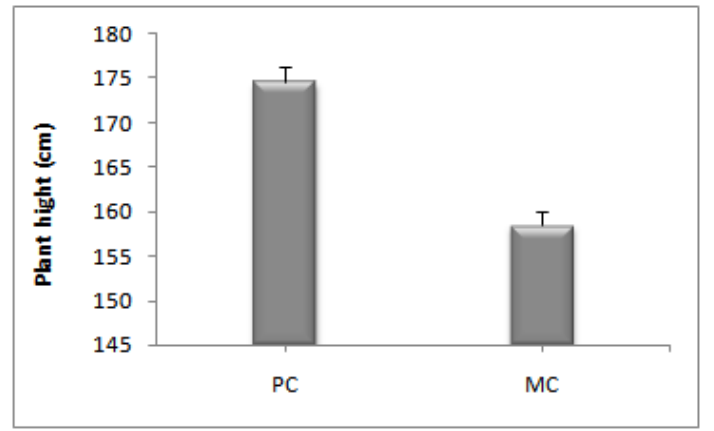

Figure3.2. Effect of compost types on plant height $(\mathrm{cm})$

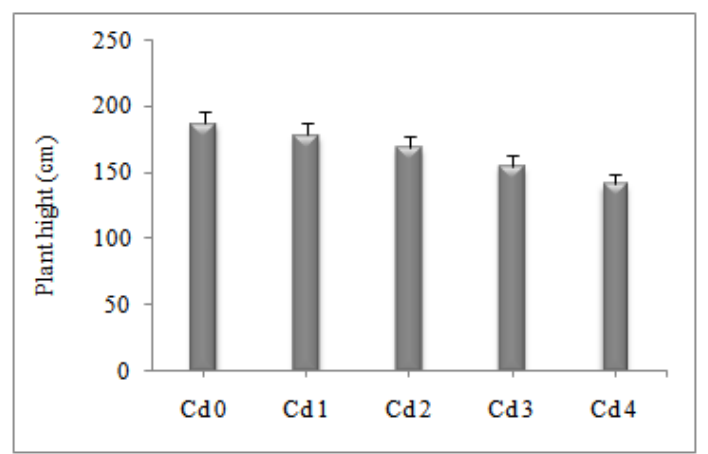

Figure3.3. Effect of cadmium levels on plant height $(\mathrm{cm})$

The interaction between the soil's $\mathrm{pH}$ levels and compost types substantially affected the growth rate of plant height. The interaction between $\mathrm{pH} 4$ and PC resulted in the highest rate that reached 197.65 $\mathrm{cm}$, which is remarkably superior over other interactions. This increase can be caused by the availability of the main cations, especially calcium, which leads to the soil's $\mathrm{pH}$ increase, consequently providing the correct environment for nutrient release that increase corn growth (Rastijia et al., 2012). These results agree with those reported by Andric et al. (2010). The interaction between $\mathrm{pH} 4$ and MC resulted in the least plant height rate, reaching $131.05 \mathrm{~cm}$ Figure 3.4, and this decrease is most likely caused by the influence of decreased soil $\mathrm{pH}$ in its un-readiness in absorbing main nutrients such as N and P (Kisinyo et al., 2009).

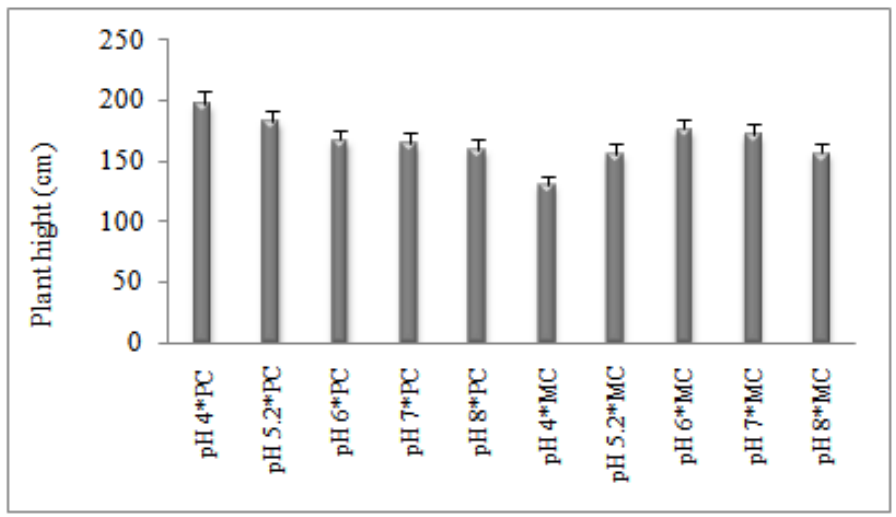

Figure3.4. Effect of interaction between soil pH levels and compost types on plant height (cm)

The interaction between PC and Cd 0 is remarkably superior over other interactions between $\mathrm{Cd}$ and compost types, where it results in the highest rate of plant height, reaching $192.63 \mathrm{~cm}$ as opposed to the lowest rate that reached $128.46 \mathrm{~cm}$ in the interaction between $\mathrm{MC}$ and $\mathrm{Cd} \mathrm{4}$, Figure 3.5. This increase occurs in the interaction between PC and $\mathrm{Cd} 0$, most likely caused by the effect of the availability of the nutrients in the soil via the addition of PC and the unavailability of $\mathrm{Cd}$, which negatively affect plant growth in general (Chen et al., 2004). In terms of the interaction between the levels of soil $\mathrm{pH}$ and $\mathrm{Cd}$ in the soil, the interaction between $\mathrm{pH} 6$ and $\mathrm{Cd} 0$ substantially affected the increase of the plant height, and its highest rate reached $194.27 \mathrm{~cm}$, while the interaction between $\mathrm{pH}$ 8 and $\mathrm{Cd} 4$ resulted in the lowest rate of $139.58 \mathrm{~cm}$, as shown in Figure 3.6. 


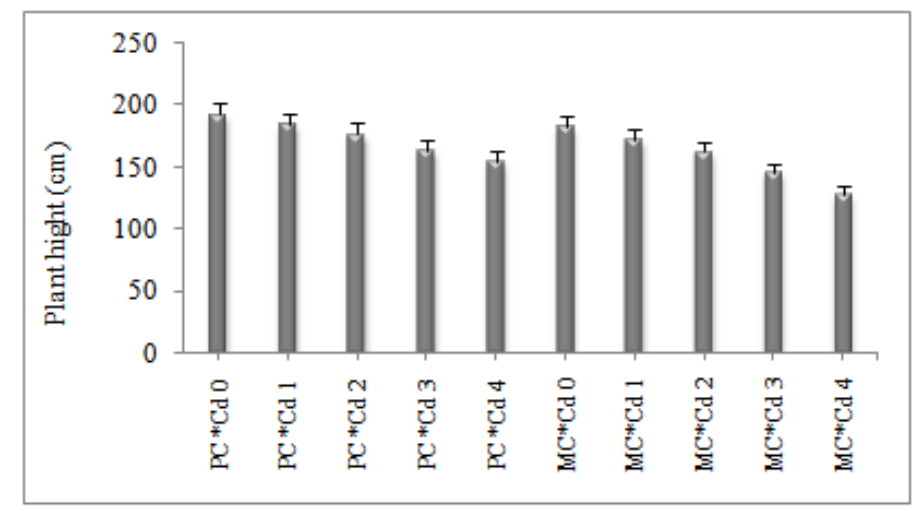

Figure3.5. Effect of interaction between compost types and cadmium levels on plant height (cm)

Figure 3.7 showed a substantial interaction between the three factors of study in the increase of the plant height, where the interaction between the $\mathrm{pH} 4$ and $\mathrm{PC}$ and $\mathrm{Cd} 0$ resulted in the highest plant, reaching $218.20 \mathrm{~cm}$, which might be caused by PC in increasing the soil's $\mathrm{pH}$ from $\mathrm{pH} 4$ to $\mathrm{pH} 6.48$ Figure 4.3.1. It helped introduce nutrients into the soil via PC and decrease the concentration of $\mathrm{Cd}$, which led to the plant absorbing nutrients and growth in height. In terms of the interaction between $\mathrm{pH} 8$ and $\mathrm{MC}$ and $\mathrm{Cd} \mathrm{4}$, it resulted in the lowest of plant growth at $127.17 \mathrm{~cm}$. This decrease is most likely caused by the soil's $\mathrm{pH}$ decreasing, which in turn increases the readiness of $\mathrm{Cd}$ and its corresponding movement in the soil (Hong et al., 2008), which simultaneously decreases the readiness of the competitive nutrients, especially that of compost MC that did not influence the value of the soil's $\mathrm{pH}$ compared to $\mathrm{PC}$ containing calcium and magnesium, which in turn increased the $\mathrm{pH}$ of the soil (Fan et al., 2014).

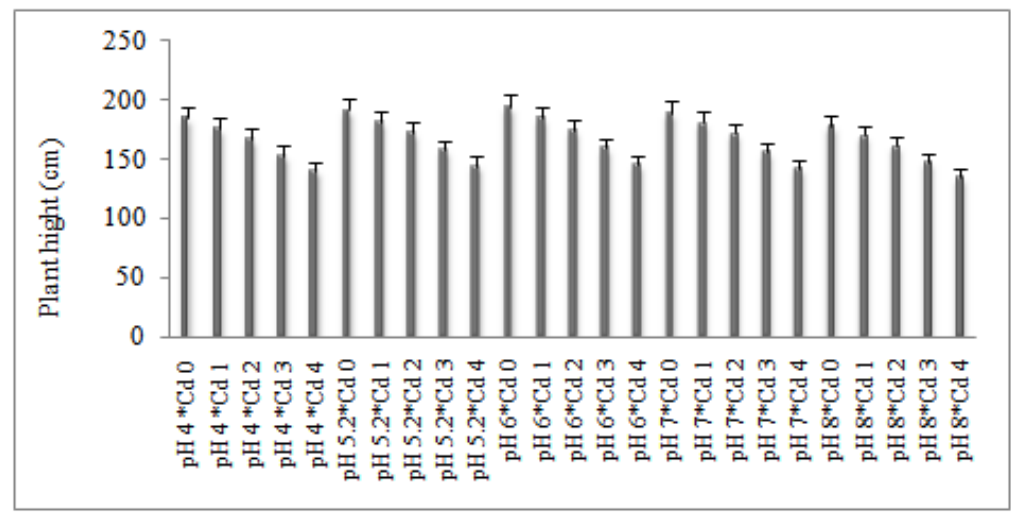

Figure3.6. Effect of interaction between soil $\mathrm{pH}$ levels and cadmium levels on plant height (cm)

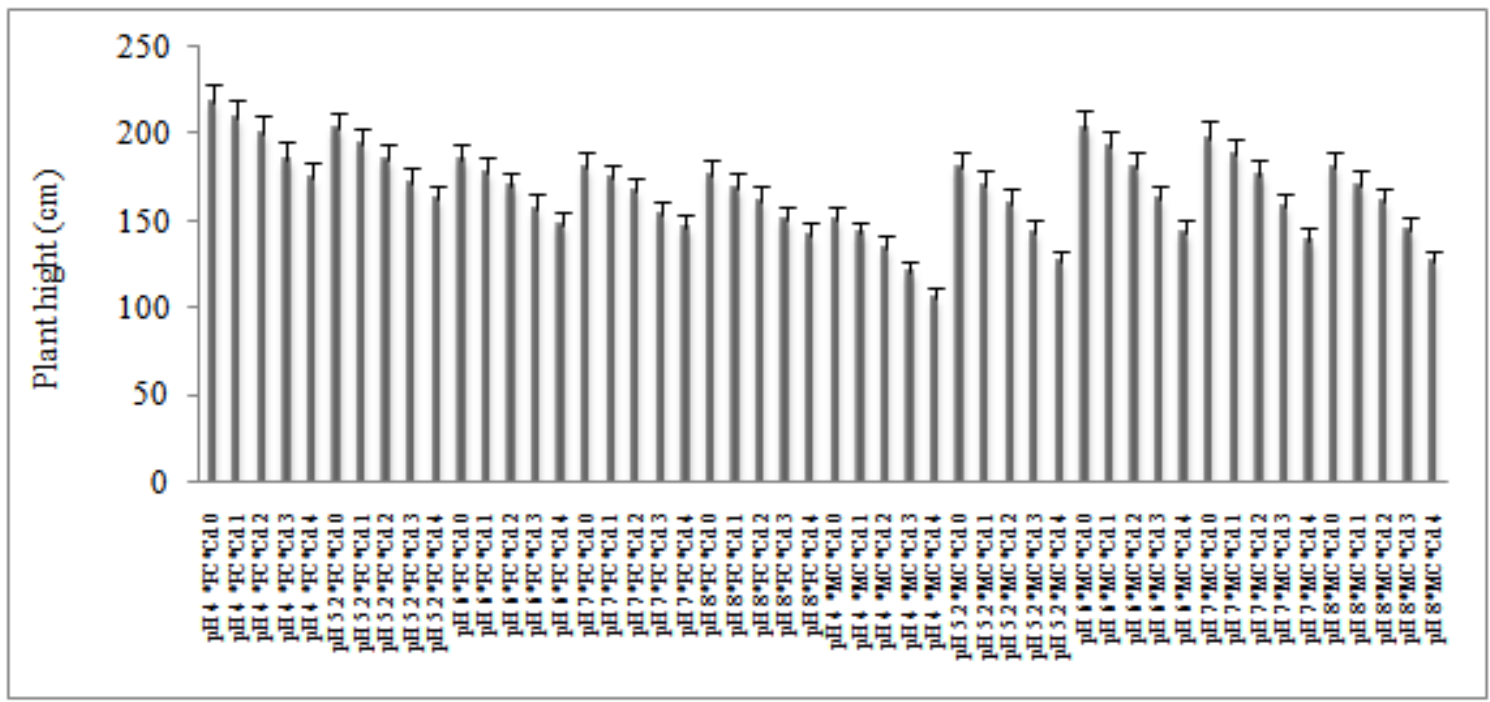

Figure3.7. Effect of interaction between soil pH levels and compost types and cadmium levels on plant height (cm) 


\subsection{Leaf Area $(\mathrm{Cm} 2)$}

The leaf area is regarded as an indicator of the photosynthesis system and a main source of dry matter, meaning that is has a strong relationship with growth characteristics. The difference in the levels of soil $\mathrm{pH}$ led to big differences in the leaf area for plants Figure 3.8, where the $\mathrm{pH} 6$ level resulted in the highest leaf area, reaching $4809.78 \mathrm{~cm} 2$, which might be caused by the increase of competency of nutrients absorbance by plants, especially $\mathrm{N}$, regarded as one of the most important macronutrients that interferes with bio-activities. It influences the division of cells and increase plant growth, including its leaf area (Binder et al., 2000), while giving pH 8 lower plant leaf area, reaching $4263.89 \mathrm{~cm} 2$.

Figure 3.9 showed big differences in the leaf area between the two types of compost PC and MC, where the former gave the highest leaf area reached $5028.41 \mathrm{~cm} 2$, while the latter gave the lowest leaf area that reached $4167.17 \mathrm{~cm} 2$, most likely caused by the availability of calcium in PC at levels higher than MC. Calcium is regarded as an important element in biological processes for plants, as it hugely effects the division of cells. and increasing size of the leaf and consequently increased the photosynthesis, and that reflected positively on the leaf area of plant (Abdelrazzag, 2002). These results agree with the one reported by Unagwu et al. (2013). Also, the decrease of the plant leaf area is inversely proportional to the levels of $\mathrm{Cd}$ in the soil, Figure 3.10. Cd 0 gave the highest plant leaf area that reached $5078.04 \mathrm{~cm} 2$, compared to $\mathrm{Cd} 4$, which gave the lowest $4008.54 \mathrm{~cm} 2$. This decrease might be caused by the effect of $\mathrm{Cd}$ in absorption and transfer of the nutrients within the plants from the roots to the leaves across the conducting xylem tissue (Sandalio et al., 2001).

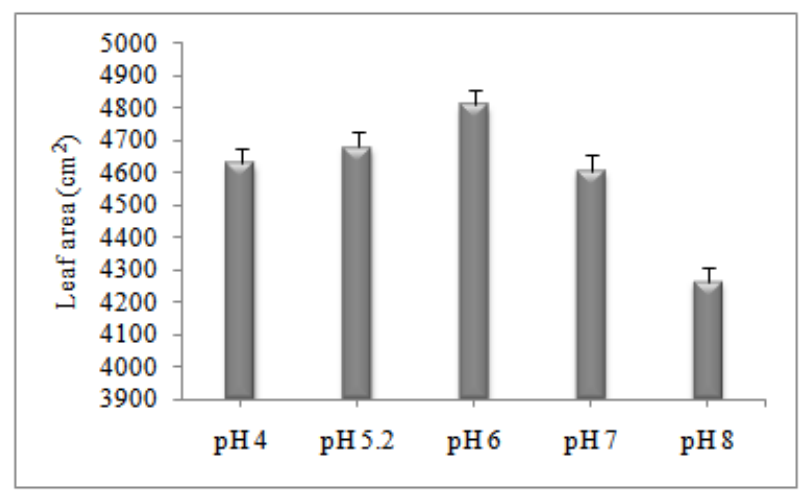

Figure3.8. Effect of soil pH levels on leaf area $\left(\mathrm{cm}^{2}\right)$

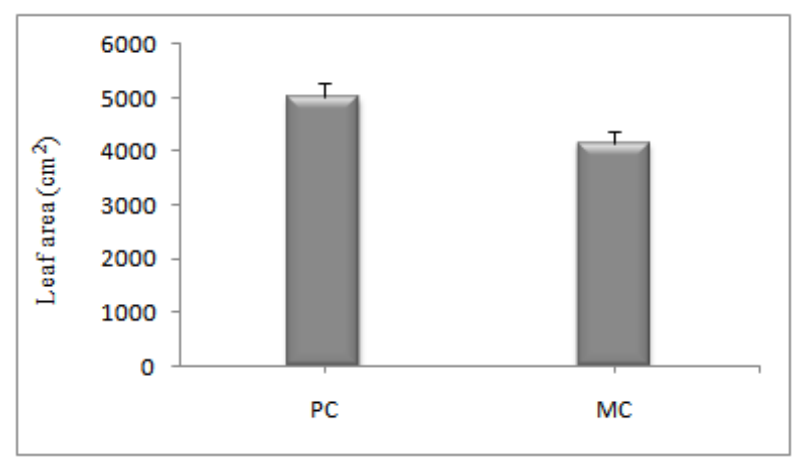

Figure3.9. Effect of compost types on leaf area $(\mathrm{cm} 2)$

In terms of interactions between the study factors, those between $\mathrm{pH} 4$ and PC substantially affected the increase of leaf area for plants Figure 3.11, where it resulted in the highest rate, reaching 6016.58 $\mathrm{cm} 2$, which might be due to the effect of the types of compost in increasing the $\mathrm{pH}$ of the soil until it reaches a level where most nutrients are ready for absorption by the plant, especially those that are available in high quantities in the same compost PC (Andric et al., 2010). Whereas the interaction between $\mathrm{pH} 4$ and $\mathrm{MC}$ resulted in the lowest plant leaf area, at $3341.77 \mathrm{~cm} 2$.

The results confirmed the presence of substantial interactions between the compost types and $\mathrm{Cd}$ levels, where the interaction between PC and Cd 0 substantially affected the leaf area for the plant over other interactions Figure3.12, where it resulted in the highest rate at $5370.58 \mathrm{~cm} 2$, which might be caused by the presence of nutrients such as N, P, and Ca. These nutrients enhances root growth and 
the division of cells, which subsequently translate into increased growth and decreased $\mathrm{Cd}$, while the decrease of plant leaf area appears to be the effect of the increase in the level of $\mathrm{Cd}$ in the rest of the interactions, especially in $\mathrm{MC}$, where the $\mathrm{Cd}$ enter in plant leaves via calcium channels due to the shortage of $\mathrm{Ca}$ in the soil, leading to the closing of the stomata, which leads to decrease the rate of transpiration, and inhibition of photosynthesis in the plant (Perfus-Barbeoch et al., 2002), while interactions between $\mathrm{MC}$ and $\mathrm{Cd} 4$ resulted in the least plant leaf area that reached $3384.57 \mathrm{~cm} 2$. The interaction between $\mathrm{pH} 6$ and $\mathrm{Cd} 0$ substantially effected the increase in the plant leaf area Figure 3.13 , where it resulted in the highest $5331.69 \mathrm{~cm} 2$. This level of soil $\mathrm{pH}$ is suitable for uptaking nutrients from soils (Sadullah, 1999), especially at lower levels of $\mathrm{Cd}$, where the least rate reached were $3703.28 \mathrm{~cm} 2$ in the interaction between $\mathrm{pH} 8$ and $\mathrm{Cd} 4$.

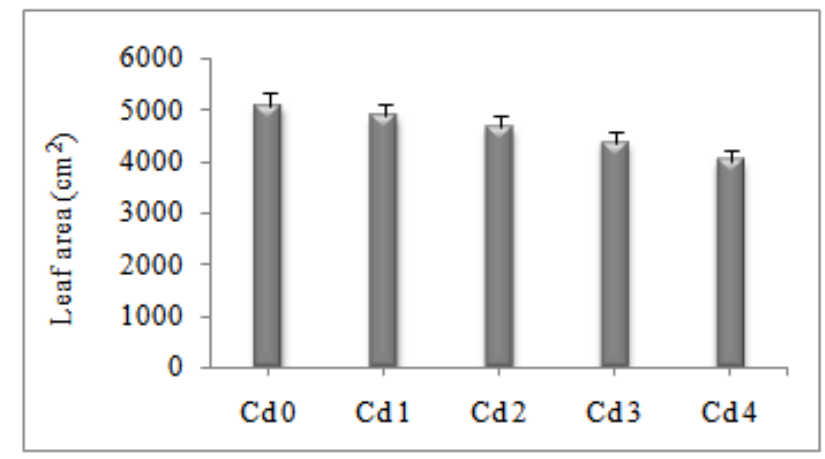

Figure3.10. Effect of cadmium levels on leaf area (cm2)

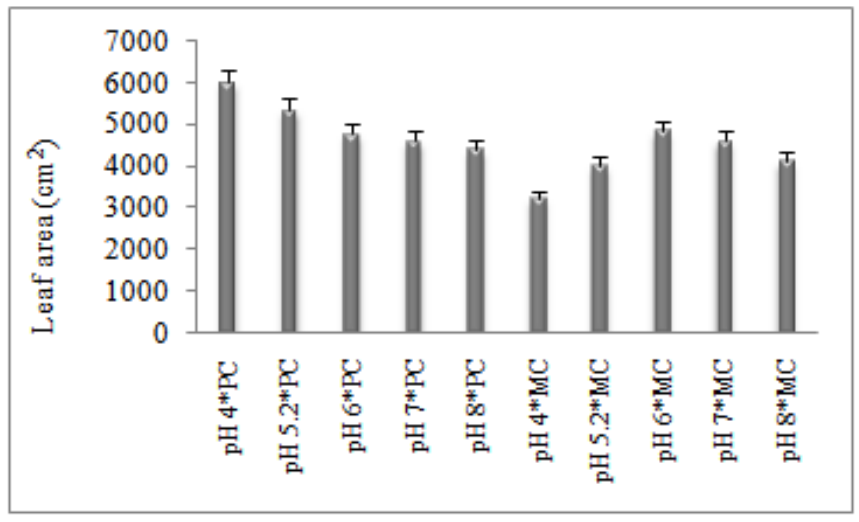

Figure3.11. Effect of interaction between soil pH levels and compost types on leaf area (cm2)

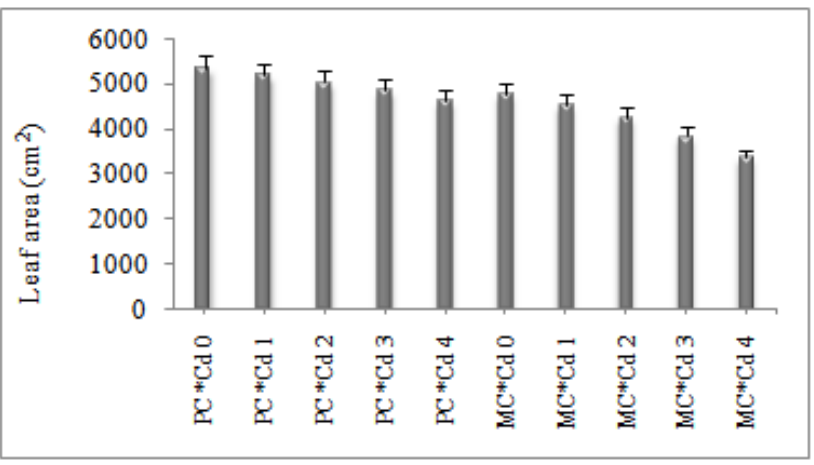

Figure3.12. Effect of interaction between compost types and cadmium levels on leaf area ( $\mathrm{cm} 2)$

In terms of the interaction between the three factors of the study, Figure 3.14 showed a substantial effect of the levels of soil $\mathrm{pH}$ and the compost types used and Cd levels, where the interaction between $\mathrm{pH} 4$ and PC and $\mathrm{Cd} 0$ is remarkably superior over all other interactions in the study in providing the highest rate of plant leaf area that reached $6425.99 \mathrm{~cm} 2$. This result might be caused by the PC effect on soil's $\mathrm{pH}$ increasing from $\mathrm{pH} 4$ to $\mathrm{pH} 6.48$ Due to the presence of high calcium and the availability and readiness of the nutrients to be absorbed and decreasing the concentration of $\mathrm{Cd}$ that led to increased growth that generally includes increased leaf area for plants, while the interaction 
between $\mathrm{pH} 4$ and $\mathrm{MC}$ and $\mathrm{Cd} 4$ gave the least that reached $2632.97 \mathrm{~cm} 2$. This might have been caused by Cd's readiness, due to its high concentration and decreased $\mathrm{pH}$ in this treatment (Shaheen et al., 2013; Teng et al., 2015) and the inability of the MC compost to increase the soil's pH that led to the absorption of high quantities of $\mathrm{Cd}$, leading to a decrease in the leaf area and plant growth.

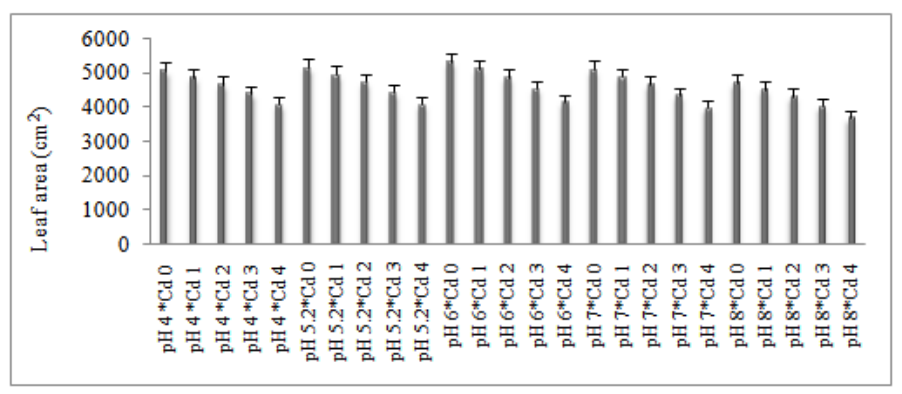

Figure3.13. Effect of interaction between soil pH levels and cadmium levels on leaf area $(\mathrm{cm} 2)$

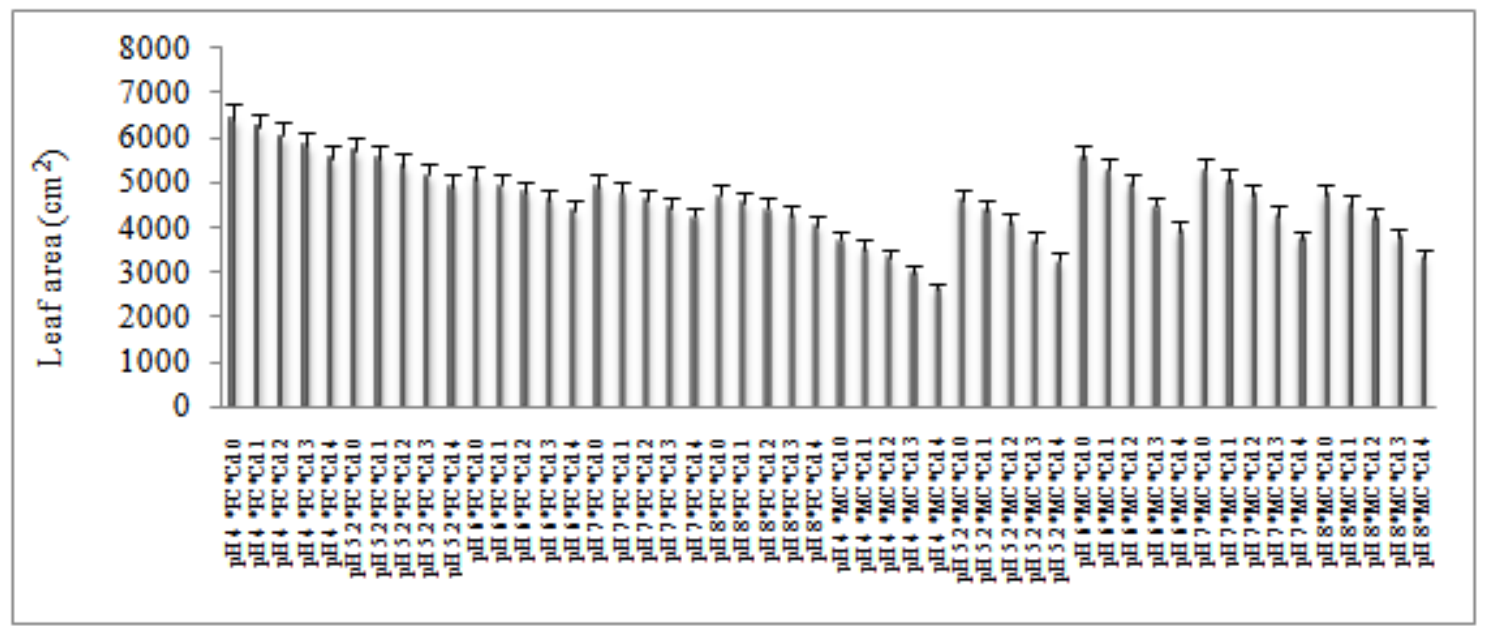

Figure3.14: Effect of interaction between soil pH levels and compost types and cadmium levels leaf area (cm2)

\subsection{Leaf Area Index}

This characteristic identifies the efficiency of sunray interception and reflects the optimum level of the leaf area that produces the highest amount of dry matter (Al Jobouri and Anwer, 2010). Figure 3.15 indicated the highly superiority of $\mathrm{pH} 6$ over other levels, where gave the highest rate at 2.55, compared with $\mathrm{pH} 8$, which resulted in the lowest rate at 2.27. Also, similar effects of the increase of the leaf area is reflected on the increase of the leaf area index at all treatments, where the PC was remarkably superior on MC in the leaf area index, where it resulted in the highest rate of 2.67, compared with MC type, which resulted in the lowest rate at 2.21 Figure3.16. This might have been caused by the increase the leaf area Figure 3.9 at the same treatment PC, which positively reflected on the leaf area index (Al Jobouri and Anwer, 2010; Cavagnaro, 2014). The Cd 0 was remarkably superior to all Cd levels Figure 3.17, where its highest was at 2.70, compared to the lowest at 2.13 at Cd 4 (Sandalio et al., 2001).

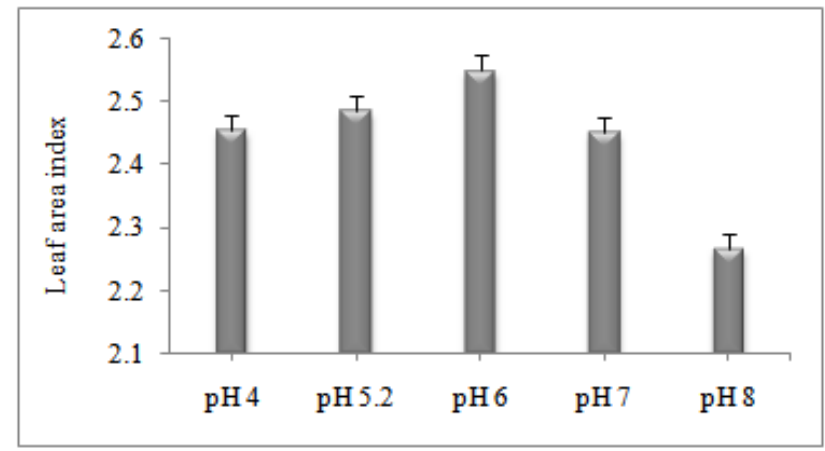

Figure3.15. Effect of soil $p H$ levels on leaf area index 

(Zea Maysl.)

The reflection of increased leaf area could explain the increase in the leaf area index. It did not only influence individual treatments, it also reflected the dual and triple interactions, where dual interactions between $\mathrm{pH} 4$ and $\mathrm{PC}$, interaction between $\mathrm{PC}$ and $\mathrm{Cd} 0$, and the interaction between $\mathrm{pH}$ 6 and $\mathrm{Cd} 0$ and the triple interaction between $\mathrm{pH} 4$ and $\mathrm{PC}$ and $\mathrm{Cd} 0$ resulted in the highest leaf area index that reached $(3.19,2.85,2.83$ and 3.41 respectively), which were remarkably superior to the rest of dual and triple interactions of the study, where the dual interactions between $\mathrm{pH} 4$ and $\mathrm{MC}$, interaction between $\mathrm{MC}$ and $\mathrm{Cd} 4$, and the interaction between $\mathrm{pH} 8$ and $\mathrm{Cd} 4$ and the triple interaction between $\mathrm{pH} 4$ and $\mathrm{MC}$ and $\mathrm{Cd} 4$ resulted in the lowest leaf area index that reached (1.72, 1.80, 1.97 and 1.40 respectively). These results agreed with (Hameed and Ahmed, 2006 ; Al Jobouri and Anwer, 2010), as shown in Figures 3.18 to 3.21.

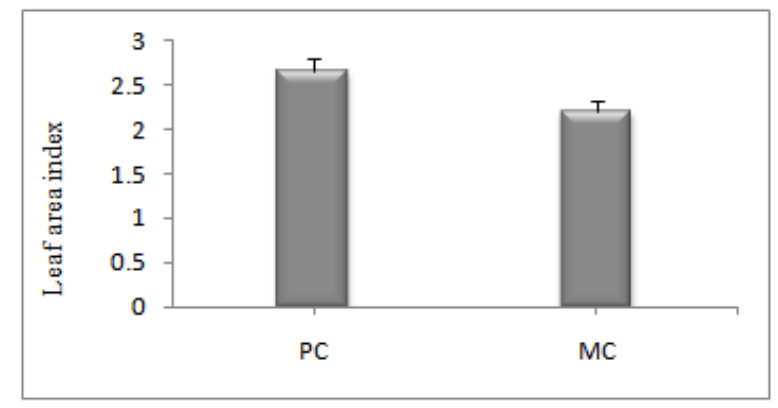

Figure3.16. Effect of compost types on leaf area index

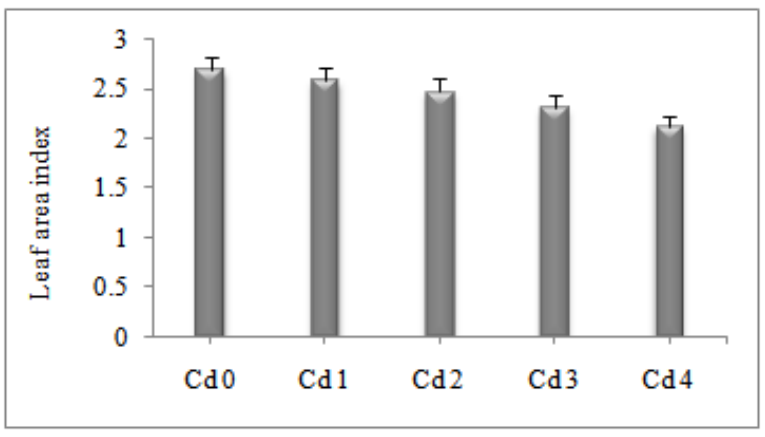

Figure3.17. Effect of cadmium levels on leaf area index

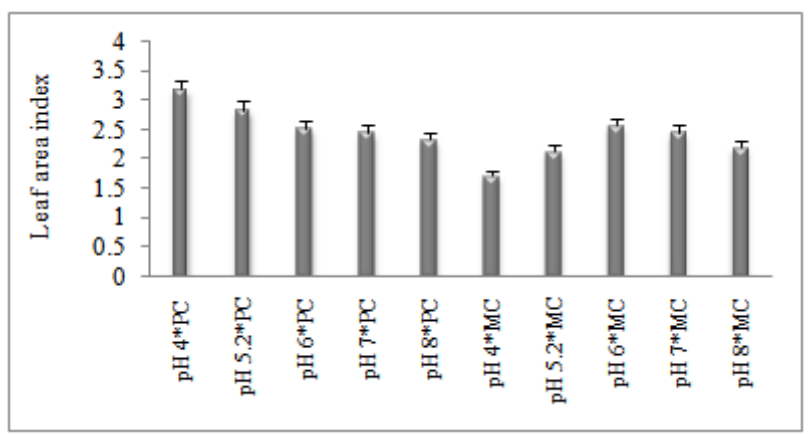

Figure3.18. Effect of interaction between soil pH levels and compost types on leaf area index

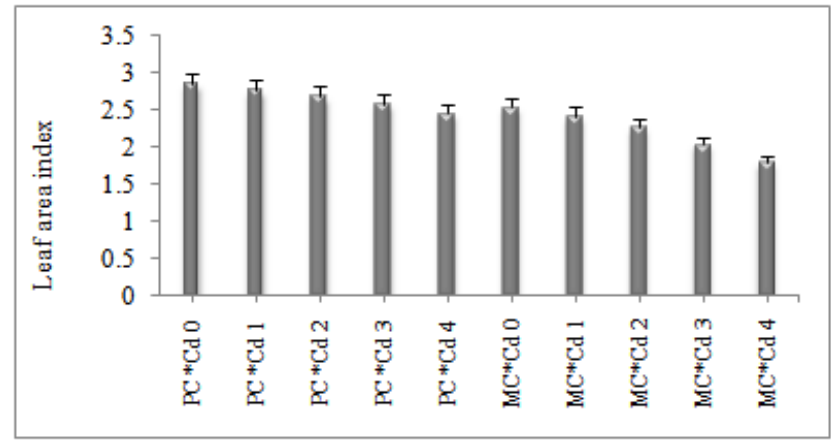

Figure3.19. Effect of interaction between compost types and cadmium levels on leaf area index 


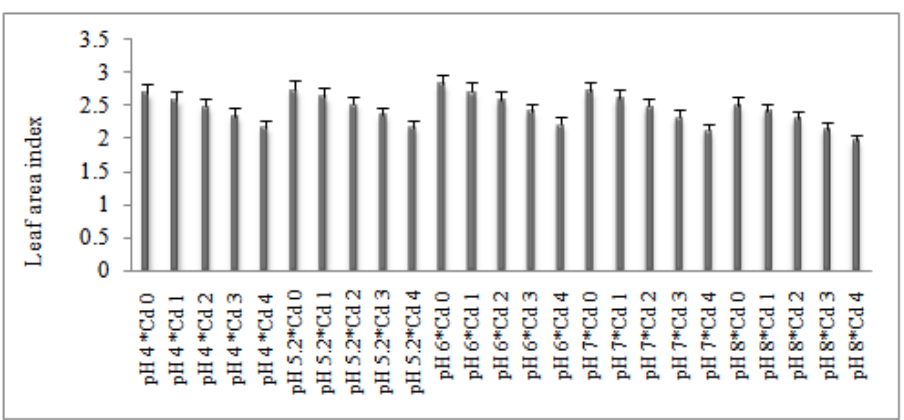

Figure3.20. Effect of interaction between soil pH levels and cadmium levels on leaf area index

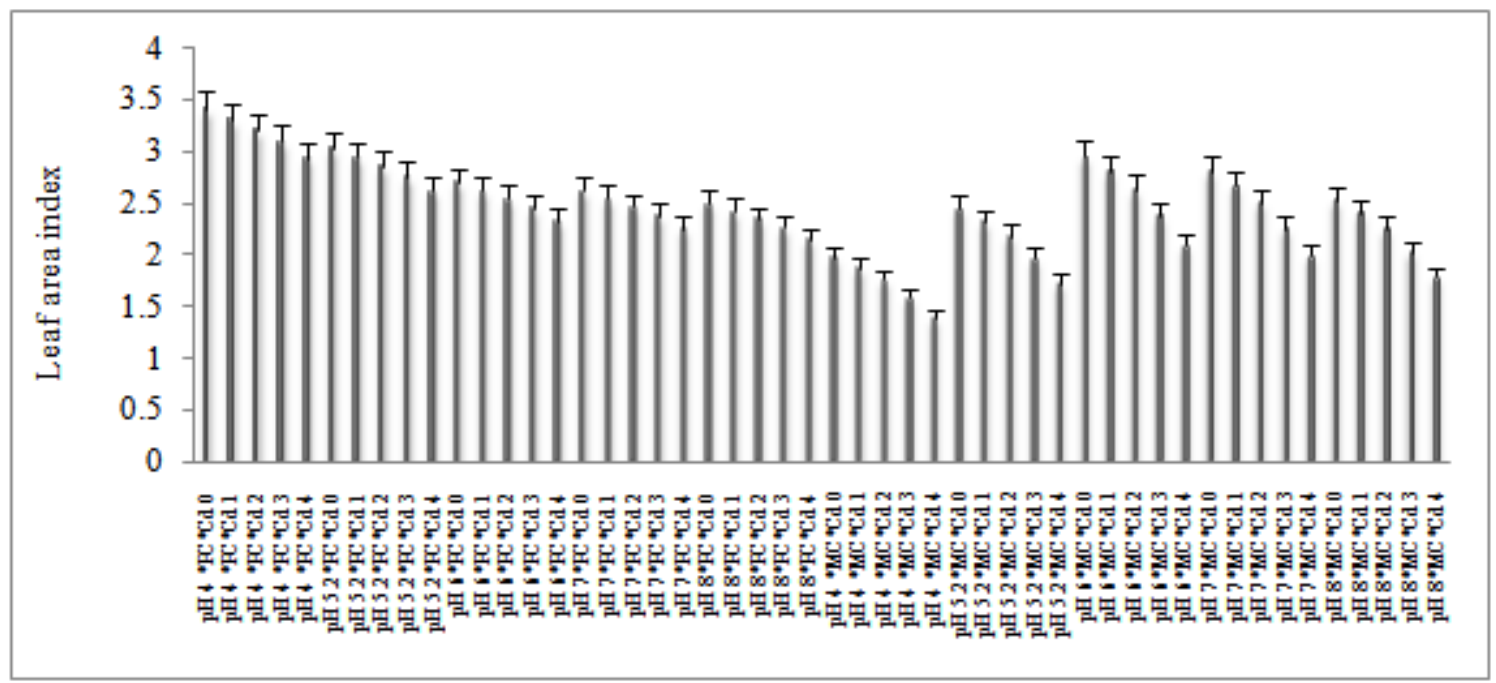

Figure3.21. Effect of interaction between soil pH levels and compost types and cadmium levels on leaf area index

\section{CONCLUSION}

The study noted to the importance of the $\mathrm{pH}$ of soil for the growth of corn where that decreased soil $\mathrm{pH}$ to less than $\mathrm{pH} 6$, also increase it more than $\mathrm{pH} 7$ lead to the general weakness in the growth characters (plant height, Leaf area and Leaf area index). As well as, the decrease of soil $\mathrm{pH}$ led to increased negative impact of toxic cadmium which significantly affected plant growth when increasing it, leading to the future impact in decreased the corn production So it must be emphasized that the $\mathrm{pH}$ of the soil and methods of increase it, especially in soils contaminated by the element cadmium. Adding high-calcium compost is also necessary for both soil and plant where calcium helps to increase plant growth, as well as helps increase $\mathrm{pH}$ of the soil which helps reduce the absorption of cadmium.

\section{REFERENCES}

[1] Abdelrazzag, A. (2002). Effect of chicken manure, sheep manure and inorganic fertilizer on yield and nutrients uptake by onion. Pak. J. Biol. Sci,5, 266-268.

[2] Al Jobouri, S. M., \&Anwer, A. M. (2010). Influence of Different Levels and Application Dates of Nitrogen Fertilizer on Growth of Two Corn Varieties (Zea mays L.). Jordan Journal of Agricultural Sciences, 5(1), 57-72.

[3] Amani, A. L. (2008). Cadmium induced changes in pigment content, ion uptake, proline content and phosphoenolpyruvate carboxylase activity in Triticum aestivum seedlings. Aust J Basic Appl Sci, 2(1), 57-62.

[4] An, Y. J. (2004). Soil ecotoxicity assessment using cadmium sensitive plants. Environmental Pollution, 127(1), 21-26.

[5] Andric, L., Banaj, D., \&Jambrovic, A. (2010). Impacts of liming on maize and soil status. In Növénytermelés (Vol. 59, No. Supplement, pp. 61-64). AkadémiaiKiadó.

[6] Auda, Mohamed Abou, Ismail Abu Zinada, \& Emad El Shakh Ali(2011). Accumulation of heavy metals in crop plants from Gaza Strip, Palestine and study of the physiological parameters of spinach plants. Journal of the Association of Arab Universities for Basic and Applied Sciences 10.1: 21-27. 
[7] Benavides, M. P., Gallego, S. M., \&Tomaro, M. L. (2005). Cadmium toxicity in plants. Brazilian Journal of Plant Physiology, 17(1), 21-34.

[8] Binder, D. L., Sander, D. H., \& Walters, D. T. (2000). Maize response to time of nitrogen application as affected by level of nitrogen deficiency. Agronomy Journal, 92(6), 1228-1236.

[9] Bolan, N. S., Adriano, D. C., Mani, P. A., \&Duraisamy, A. (2003). Immobilization and phytoavailability of cadmium in variable charge soils. II. Effect of lime addition. Plant and Soil, 251(2), 187-198.

[10] Cavagnaro, T. R. (2014). Impacts of compost application on the formation and functioning of arbuscular mycorrhizas. Soil Biology and Biochemistry,78, 38-44.

[11] Chen, Y., Clapp, C. E., \& Magen, H. (2004). Mechanisms of plant growth stimulation by humic substances: The role of organo-iron complexes. Soil Science and Plant Nutrition, 50(7), 1089-1095.

[12] Cynthia, G., Don, F., Mario, T., Xiaopeng, G., Sukdev, M. and Eugene, G. (2010). Impact of long-term application of phosphate fertilizer on cadmium accumulation in crops. Soil Science Australalia, 1, 132-134.

[13] De Jong, F. (2007). Marine eutrophication in perspective: on the relevance of ecology for environmental policy. Springer Science \& Business Media.

[14] Desalegn, G., Binner, E., Lössl, A., Vierheilig, H., Liebhard, P., \& Lechner, P. (2014). Influence of quality compost on plant growth and mycorrhizal colonisation in corn. Universität fürBodenkultur Wien Department fürAngewandtePflanzen-wissenschaften und Pflanzenbiotechnologie. Retrieved on, 5.

[15] Ekmekci, Y., Tanyolac, D., \&Ayhan, B. (2008). Effects of cadmium on antioxidant enzyme and photosynthetic activities in leaves of two maize cultivars. Journal of plant physiology, 165(6), 600-611.

[16] Fan, J., He, Z., Ma, L. Q., Yang, Y., \&Stoffella, P. J. (2014). Impacts of calcium water treatment residue on the soil-water-plant system in citrus production. Plant and soil, 374(1-2), 993-1004.

[17] Fernández, F. G., \&Hoeft, R. G. (2009). Managing soil pH and crop nutrients. Illinois agronomy handbook, 91-112.

[18] Giller, K. E. (2001). Nitrogen fixation in tropical cropping systems. Cabi.

[19] Hameed, K. Al. \& Ahmed, N. Al. (2006). Effect of source, rate and splitting of phosphorus fertilizers on maize performance. The Iraqi Journal of Agricultural Sciences, 37 (6): 35-42.

[20] Hong, C. O., Lee, D. K., \& Kim, P. J. (2008). Feasibility of phosphate fertilizer to immobilize cadmium in a field. Chemosphere, 70(11), 2009-2015.

[21] Ilyas, M., Ayub, G., \& Hussain, Z. (2014). Response of Tomato to Different Levels of Calcium and Magnesium Concentration. World Applied Sciences Journal, 31(9), 1560-1564.

[22] John, N. M., Uwah, D. F., Iren, O. B., \& Akpan, J. F. (2013). Changes in Maize (Zea mays L.) Performance and Nutrients Content with the Application of Poultry Manure, Municipal Solid Waste and Ash Composts. Journal of Agricultural Science, 5(3), 270.

[23] Kader, M. A., \& Lindberg, S. (2010). Cytosolic calcium and pH signaling in plants under salinity stress. Plant signaling \& behavior, 5(3), 233-238.

[24] Kimatu, J. N. (2015). Correlating aluminium toxicity, heterosis and epigenetic mechanisms in maize yield improvement in acid soils. Biotechnology and Molecular Biology Reviews, 10(2), 12-18.

[25] Kirkham, M. B. (2006). Cadmium in plants on polluted soils: effects of soil factors, hyperaccumulation, and amendments. Geoderma, 137(1), 19-32.

[26] Kisinyo, P., Gudu, S., Othieno, C., Okalebo, J., Ochuodho, J., Agalo, J., Ng’etich, W., Opala, P., Maghanga, J., Osiyo, R. and Ligeyo, D. (2009). Residual effects of lime and phosphorus applications on soil and maize (Zea mays L.) performance in a Kenyan highlands acid soil. Journal of Agriculture, Pure and Applied Science and Technology, 2073-8749.

[27] Kukier, U., Peters, C. A., Chaney, R. L., Angle, J. S., \&Roseberg, R. J. (2004). The effect of pH on metal accumulation in two species. Journal of Environmental Quality, 33(6), 2090-2102.

[28] Laekemariam, F., \&Gidago, G. (2012). Response of Maize (Zea mays L.) to integrated fertilizer application in Wolaita, South Ethiopia. Advances in Life Science and Technology, 5, 21-30.

[29] Li, X., Ziadi, N., Bélanger, G., Cai, Z., \& Xu, H. (2011). Cadmium accumulation in wheat grain as affected by mineral N fertilizer and soil characteristics. Canadian Journal of Soil Science, 91(4), 521-531.

[30] Madani, B., Mohamed, M. T. M., Awang, Y., Kadir, J., \& Patil, V. D. (2013). Effects of calcium treatment applied around the root zone on nutrient concentrations and morphological traits of papaya seedlings (Carica papaya L. cv. Eksotika II). Australian Journal of Crop Science, 7(5), 568.

[31] Makinde, E.A. (2007). Effects of an organol-mineral fertilizer application on the growth and yield of maize. Journal of Applied Science Research, 3, 1152-1155. 
[32] Musharo, C. (2005). Tolerance of Selected Maize (Zea Mays L.) and Soyabean (Glycine Max L. Merr.) Cultivars to Soil Acidity (Doctoral dissertation, University of Zimbabwe).

[33] Ozgen, S., Busse, J. S., \& Palta, J. P. (2011). Influence of root zone calcium on shoot tip necrosis and apical dominance of potato shoot: simulation of this disorder by ethylene glycol tetra acetic acid and prevention by strontium. HortScience, 46(10), 1358-1362.

[34] Payne, R.W., Murray, D.A., Harding, S.A., Baird, D.B. \&Soutar, D.M., (2012). Introduction to GenStat ${ }^{\circledR}$ for Windows ${ }^{\mathrm{TM}}$ (15th Edn), VSN International, Hemel Hempstead, Hertfordshire, UK. C) 2012 VSN International.

[35] Perfus-Barbeoch, L., Leonhardt, N., Vavasseur, A., \& Forestier, C. (2002). Heavy metal toxicity: cadmium permeates through calcium channels and disturbs the plant water status. The Plant Journal, 32(4), 539-548.

[36] Prasad, M. N. V., Greger, M., \&Landberg, T. (2001). Acacia nilotica L. bark removes toxic elements from solution: corroboration from toxicity bioassay using Salix viminalis L. in hydroponic system. International Journal of Phytoremediation, 3(3), 289-300.

[37] Qiu, H., Huang, J., Yang, J., Rozelle, S., Zhang, Y., Zhang, Y., \& Zhang, Y. (2010). Bioethanol development in China and the potential impacts on its agricultural economy. Applied Energy, 87(1), 76-83.

[38] Rastijia, D., Semialjac, Z., Rastija, M., \&Gulisija, A. (2012). Residual effect of liming on soil properties and maize grain yield. In Third International Scientific Symposium (pp. 87-91).

[39] Sadullah N. Al. (1999). Fertilizers and soil fertility. Ministry of Higher Education and Scientific Research. University of Al-Mosul. Book.

[40] Sandalio, L. M., Dalurzo, H. C., Gomez, M., Romero-Puertas, M. C., \& Del Rio, L. A. (2001). Cadmium-induced changes in the growth and oxidative metabolism of pea plants. Journal of experimental botany, 52(364), 2115-2126.

[41] Shaheen, S. M., Tsadilas, C. D., \&Rinklebe, J. (2013). A review of the distribution coefficients of trace elements in soils: Influence of sorption system, element characteristics, and soil colloidal properties. Advances in colloid and interface science, 201, 43-56.

[42] Shi, Y. (2014). Corn Plant Location, Spacing and Stalk Diameter Measurement Using Optical Sensing Technologies.

[43] Shrivastava, P., \& Kumar, R. (2015). Soil salinity: A serious environmental issue and plant growth promoting bacteria as one of the tools for its alleviation. Saudi Journal of Biological Sciences, 22(2), 123-131.

[44] Teng, Y., Feng, D., Wu, J., Zuo, R., Song, L., \& Wang, J. (2015). Distribution, bioavailability, and potential ecological risk of $\mathrm{Cu}, \mathrm{Pb}$, and $\mathrm{Zn}$ in soil in a potential groundwater source area. Environmental monitoring and assessment, 187(5), 1-14.

[45] Tran, T. A., \& Popova, L. P. (2013). Functions and toxicity of cadmium in plants: recent advances and future prospects. Turkish Journal of Botany,37(1), 1-13.

[46] Unagwu, B.O., Asadu, C.L.A. \&Ezeaku, P. I. (2013). Residual Effects of Organic and NPK Fertilizers on Maize Performance at Different Soil pH Levels. IOSR Journal of Agriculture and Veterinary Science, 5 (5): 47-53.

[47] Watson, D. (1952). The physiological basis of variation in yield. Adv. Agron,4(1), 101-145.

[48] Wessels, C. F. (2014). Response of a sandy soil and maize plants to zinc fertilizers.Department of Soil, Crop and Climate Sciences. Faculty of Natural and Agricultural Sciences. University of the Free State. Bloemfontein

[49] Weyman-Kaczmarkowa, W., \&Pędziwilk, Z. (2000). The development of fungi as affected by pH and type of soil, in relation to the occurrence of bacteria and soil fungistatic activity. Microbiological research, 155(2), 107-112.

Citation: Rabah S. Shareef, et.al., (2019).” The Effect of Soil PH, High-Calcium Compost and Cadmium on Some of Growth Characters in Corn (Zea maysl.)." ARC Journal of Pharmaceutical Sciences (AJPS), 5(4), pp.16-27. DOI: http://dx.doi.org/10.20431/2455-1538.0504003

Copyright: (C) 2019 Authors. This is an open-access article distributed under the terms of the Creative Commons Attribution License, which permits unrestricted use, distribution, and reproduction in any medium, provided the original author and source are credited. 